УДК 271.2.327(477+470)

\title{
SOFT POWER CONCEPT IN FOREIGN POLICY: RUSSIAN VIEW
}

\section{КОНЦЕПЦІЯ М'ЯКОЇ СИЛИ У ЗОВНІШНІЙ ПОЛІТИЦІ РОСІЙСЬКЕ БАЧЕННЯ}

\section{КОНЦЕПЦИЯ МЯГКОЙ СИЛЫ ВО ВНЕШНЕЙ ПОЛИТИКЕ: РОССИЙСКОЕ ВИДЕНИЕ}

\author{
Oleksin Y. P.
}

Doctor of pedagogical sciences, professor. Head of the Department of Public Disciplines, Educational and Scientific Institute of Law, The National University of Water and Environmental Engineering.

E-mail: oleksin_roippo@ukr.net

\section{Олексін Ю. П}

Доктор педагогічних наук, професор, завідувач кафедри суспільних дисциплін Навчально-наукового інституту права Національного університету водного господарства та природокористування. E-mail: oleksin_roippo@ukr.net

\section{Олексин Ю. П.}

Доктор педагогических наук, профессор, заведующий кафедры общественных дисциплин Учебно-научного института права Национального университета водного хозяйства и природопользования.

E-mail: oleksin_roippo@ukr.net

Abstract. The article looks into the soft power phenomenon in the foreign policy of the Russian Federation, determines measure of its influence in the adjacent regions and the opportunities for its use for implementation of Russia's geopolitical objectives. Particular attention is dedicated to the analysis of the structure of soft power as it is viewed and applied by Russia, which allows to draw conclusions about the appropriateness of using the term 'soft power' for defining the part of Russia's foreign policy and to establish the correlation between the conditions for applying soft power and its substance by comparing peculiarities of the influence of soft power in different countries.

Based on the characteristics of the original concept of soft power the article justifies the expediency of the use of the term 'soft power' with regard to Russia's foreign policy; on these grounds the articles determines the difference of soft power as an integral part of Russia's policy and the original concept, that allows to outline the structure of influence and determine the conditions for effective use of soft power instruments in Russia's foreign policy.

Key words: Soft power, influence, foreign policy, Russian Federation, structure.

Анотація. Робота присвячена дослідженню феномену «м'якої сили» в зовнішній політиці РФ. Має визначити рівень ї̈ впливу в суміжних регіонах та можливості застосування для реалізації геополітичних иүілей РФ, дослідження зв'язків між компонентами системи, через яку Росія реалізує т. з. м'яку. Особлива увага приділена аналізу структури «м'якої сили» в розумінні РФ і особливостей ї̈ застосування, щзо дозволяє зробити висновки щуодо доцільності застосовування терміну «м'яка сила» по відношенню до складової частини зовнішньої політики Росії, а також встановити залежність між умовами застосування м'якої сили та ї̈ змістом, порівнявши особливості впливу «м'якої сили» в різних краӥнах. 
На основі характеристики оригінальної концепції м'якої сили обтрунтовується доиільність використання терміну "м'яка сила» по відношенню до зовнішньої політики Росії; на иій основі визначено відмінність «м'якої сили» як складової політики Росії та оригінальної конщепції, щзо дозволяе окреслити структуру впливу та визначити умови ефективності застосування інструментів «м'якої сили» у зовнішній політиці РФ.

Ключові слова: м'яка сила, вплив, зовнішня політика, Російська Федераиія, струкmypa.

Аннотация. Работа посвящена исследованию феномена «мягкой силы» во внешней политике РФ. Направлена на определение уровня ее влияния в сопредельных регионах и возможности применения для реализации геополитических иелей РФ. Особое внимание уделено анализу структуры «мягкой сильљ» в понимании РФ и особенностям ее применения, что позволяет сделать выводы о иелесообразности применения термина «мягкая сила» по отношению к составной части внешней политики России, а также установить зависимость между условиями применения мягкой силь и ее содержанием, сравнив особенности влияния «мягкой силь» в разных ситуаџиях и регионах.

На основе характеристики оригинальной конщепции мягкой силы обосновывается цеелесообразность использования термина «мягкая сила» по отношению к внешней политике России; на этой основе определены отличие «мягкой силь» как составляющей политики России и оригинальной концепџии, позволяющей определить структуру влияния и определить условия эффективности применения инструментов «мягкой силы» во внешней политике РФ.

Ключевые слова: мягкая сила, влияние, внешняя политика, Российская Федерация, структура.

The important research results. The end of bipolar system and technical progress are the events that have in many respects defined the essence of the changes in international relations on the verge of twentieth and twenty-first centuries, leading to the loss of balance of power and emergence of the balance of opportunities, with one of its elements being the soft power.

XXI century has started the epoch of asymmetric threats. This became possible due to achievements of the scientific and technical progress and global ideological transformations. The asymmetric nature of relations stimulates states to increasingly use soft power as an instrument of its foreign policy along with the classical power. Even the biggest proponents of the classical power confrontations on the world arena have not managed to avoid this.

The foreign policy strategy of the Russian Federation of 2013 recognizes soft power as an integral part of the modern foreign policy, emphasizing on its complexity. In the context of Russia's military activity in Eastern Europe and, as a result, deterioration of its relations with western countries, effective use of soft power the instruments of which can help to achieve the same objectives with less resources is a priority for Russia. The issue whether the term soft power appropriately defines the instruments of Russia's foreign policy is debatable, notwithstanding its use in the official document.

Eastern European region may be viewed as such that lies within the area of interest of Russia. Eastern Europe, according to many geopolitical concepts, is a key region for strengthening of the Russia's role on international arena. From the perspective of Russia's foreign policy interests, Eastern European region can be conditionally divided into several parts, one of them being post-soviet states. Another not least important sub region are the former member-states of the Warsaw pact, particularly the Visegrad Group - Poland, Czech Republic, Slovak Republic and Hungary. 
Analyzing the influence of Russia's soft power on countries' policies allows to understand geopolitical objectives and motives of Russia in the region and to predict its further steps, which is extremely important for Ukraine at the moment and other opponents of Russia on international arena in terms of theoretical and practical application.

The concept of soft power was developed by Joseph Nye Jnr. This term in its modern sense first appears in early 1990-ies in the book of J. Nye «Bound to lead: the changing nature of American power» [1]. In the same year the Foreign Policy Journal published the essay of J. Nye titled 'Soft power', which was based on ideas from this book that were directly related to the concept of soft power.

Speaking about one of the aspects of power in international relations, Nye gives of the first definitions of soft power: "The second aspect of power comes when one country is taking steps to make other country want what it wants - this can be described as cooperative of soft power unlike the rough commanding power, when others are being order to do what is needed" [2]. As a result of increasing practice of using non-military methods of influence, the term soft power gradually started to become more popular and consequently the concept of soft power required further development and definition.

Notwithstanding the fact that soft power as a factor that allows to create the so called balance of opportunities in the context of disproportionality of actor's power gained relevance only in the end of 1990-ies, as a phenomenon soft power had always been present in the policies of nation states and other actors.

Soft power foresees to make others strive for the same results as you. It is based on the capacity to formulate choice for others. Nye states that there are there main sources of power for the country: its culture, its political values, its foreign policy (in case the latter is viewed as legitimate and has authority abroad).

In the modern system of international relations there are countries which prepare the agenda for others. It is natural that these are the countries who are global leaders, first and foremost the countries characterized by the high level of economic development. However, taking into account the achievements in technological development, social and political system, religious or historical role of some countries, small countries can also be successful in setting the agenda for other countries.

If we imagine the situation that is characterized by the absence of pressure of the system (for instance the system of the bipolar world) and absence of competition for influence in the region between other actors, we can consider that countries have a possibility to freely chose the direction for their development - another country or group of countries. The degree of attractiveness of one or the other country is determined with the success of use of the soft power instruments. However, in practice, existence of only one factor determining the direction is an extremely rare phenomenon.

Notwithstanding the considerable deterioration of economic and social situation within the country, Russia has preserved the potential to be considered as a direction considered by the countries in the region and its allies on different continents (as a rule, these are the countries of anti-West convictions).

Taking this fact into account, as well as the increased popularity if the soft power on the brink of XX and XXI centuries, it is possible to consider that the use of soft power by Russia in the situation of scarce resources and regaining direct control on territories which used to be under its influence, is objective and predictable.

Beginning of the 1990-ies of the XX centuries was the period of strengthening of Russia and western world. However, already in several years under the pressure of the neo-isolationist political elites, the priorities of Russia in the field of foreign policy has changed. This is confirmed 
in the essence of the document "The main provisions of the concept of the foreign policy of Russian Federation", approved by the Resolution of the President of Russian Federation Yeltsin on 23 April 1993. [4, p.19]

Ensuring Russia's role in the world balance of influence, in multi-lateral processes in international relations, that corresponds to the status of a great power, becomes one of the priorities. Instead of integrating into the western world, development of relations with the states within the region, in particular members of the Commonwealth of Independent states, became of key importance.

Within the declared foreign policy priorities, we can clearly see the characteristics of the national interest of a state. It is natural that the soft power instruments are destined to support these interests.

As Russia has chosen its own "the particular way" and trying to meet its geopolitical ambitions and reclaim the role of a global player, the use of soft power instruments and development Russia's soft power as a whole has particular differences from the original concept, built on American experience.

During one of its public statements, J. Nye says that soft power has to be in line with the interests of others for it to be successful [6]. To identify regaining of Russia's role as a global power as one of the interests of other states - is an extremely difficult task, taking into account that Russia's leadership role is based largely on its military potential.

Use of soft power instruments by Russia has a range of peculiarities, general nature of which is best characterized by the phrase of one of the most influential ideologists of Russia's modern foreign policy Oleksandr Dugin "I believe that we also need to use art to achieve military objectives" [7].

The use of soft power instruments by Russia is a sign of its own reactive policy to the western trends of instruments of influence evolution. Russia's soft power is largely holding on its own intentions and declarations and not on social and political practices which may be of interest to other countries. Thus, the main actor that forms the essence of soft power is the state and not society.

Contemplating in his article about the use of soft power by Russian and China, J. Nye says that they are wrong when they think that the Government is the main instrument of soft power. In order to achieve success, Russia and China will have to be accountable for its words and actions in their policy, be self-critical and develop all talents of the civil societies. Summarizing, he says that regrettably this will not happen in the near future.

Historical and geographical context also play a considerable role in the nature of Russia's soft power. Having become the successor of the Soveit Union, Russia automatically obtained a number of "states-followers" among the third world countries and anti-West wing. Attractiveness of Russia for these countries was attributed to considerable military potential and Russia's industrial achievements. Thus, we can say about voluntary attractiveness of Russia for such geographically far-flung countries.

Quite a different situation is observed in the regions bordering with Russia, in particular in Eastern Europe, where Russia's strengthening threatens the countries in the region with the loss of sovereignty. This fact, and thus, the absence of common doctrinal foreign policy interests among the countries in the region and Russia justifies doubts about appropriateness of the term soft power in relation to Russia's foreign policy in this region, in particular when recalling the original concept of soft power. This difference between the Russian soft power and the original soft power concept allows to speak about so called Russian soft power when speaking about the use of a range of foreign policy instruments of non-military nature in relation to the countries of Eastern Europe. 
However, according to the authors of The Washington Post, due to the excessive emphasis on hard aspects of Russia's power, there is a risk of Russia's manipulation with soft power going unnoticed [9]. There are several reasons to speak about the Russia's use or intention to use the soft power instruments.

Firstly, this is evidenced by the official recognition of the soft power phenomenon in international politics. The Russia's Foreign Policy Concept of 2013 indicates that the soft power is becoming an integral part of the modern foreign policy. The document defines soft power as the complex set of instruments for addressing foreign policy objectives by relying on the capacity of the civil society, informational, communication, humanitarian and other methods and technologies alternative to classic diplomacy [10].

Together with the definition, the document outlines risks of destructive and illegal use of soft power "with an aim to exert political pressure on the sovereign states, interference in their internal affairs, destabilizing the situation there, manipulating public opinion, including as a part of financing of humanitarian projects and projects related to human rights protection abroad" [10]. Thus, Russia recognizes the threats deriving from the use of soft power instruments. Knowing the reactivity in the foreign policy of any state, recognition of a threat usually envisages future opposition and prevention.

The chapter of the concept dedicated to the informational accompaniment of the foreign policy activities emphasizes the importance of conveying to broad public circles full and precise information about Russia's position on the main problems of international relations, its initiatives and actions in foreign policy, processes and plans for its internal socio-economic development and Russia's cultural and technological achievements [10]. The concept also states the importance of developing own effective means of information influence on the public opinion abroad, ensuring strengthening of the position of Russian media in the world media space by providing them with required state support [10].

Russia's military doctrine of 2015 lists among threats "use of information and communication technologies to achieve military and political objectives for committing actions contrary to the international law, aimed against sovereignty, political independence, territorial integrity of states and threaten international peace, security and global and regional stability". Separately from threats, the document highlights "activities to exert information influence on population, in particular on young citizens of the country, which is aimed at undermining of the historical, spiritual, and patriotic traditions in the field of protection of the Motherland" [11].

The peculiarity of the modern armed conflicts, according to the Military doctrine, is the complex use of military force, political, economic, informational and other measures of non-military character, which is implemented through use of a broad range of protest potential of the population and use of special operations forces [11].

In addition to recognizing the existence of soft power as a phenomenon and the intent to use its instruments, the fact of use of soft power instruments takes place by engaging networks of organizations, individual organizations and individuals abroad to protection and advancement of Russia's interests. It is appropriate to say, that the use of soft power instruments by Russia has several dimensions. In order to use soft power instruments more effectively in one or the other social or political area, Russia as a rule prepares background - by starting with the use of propaganda instruments to allow for more effective use of soft power instruments in the future.

If a state can take actions, that its power is seen as legitimate by others, it will encounter less resistance on the way of implementation of its plans [2]. Thus, the main task of Russia's foreign policy is legitimizing its own actions on international arena. Some social and political practices of the western world are attractive (for instance, in Sweden: liberal values, sustainable development and functional society, implementing IT achievements into everyday life) and are fol- 
lowed abroad, while Russian practices are attractive only after discrediting the alternatives (for instance, discrediting European values, creating a figure of external enemy, etc.).

The use of the term soft power in relation to the Russian policy is appropriate. However, it is important to remember that Russia's soft power is possible in most cases soft power remains secondary to other instruments. Effectiveness of Russia's soft power instruments is directly linked to preliminary use of propaganda (or launching of advocacy or smearing campaigns).

Nevertheless, J. Nye believes that the hard power can create myths about invincibility or irreversibility, which attract others [3, c.25]. In this context, it is possible to speak about the primary nature of the soft power, however the question raises about the actors interested in this. Russia can be attractive to authoritarian regimes. Thus, undemocratic nature of Russia's soft power through its attractiveness for non-democratic regimes allows to use the term soft power precisely due to the fact that this example can be followed voluntarily.

This allows to say that one of the preconditions if not for existence as such, than for effectiveness of Russia's soft power is functioning of non-democratic regimes in the world, for which Russia is a guide. Authors of The Washington Post say that underestimating the true degree of Russia's attraction for different audiences creates the risk of further mistakes on the part of western decision makers regarding Russia's intentions [9].

The difference of Russia's soft power from the original concept and its own vision of this phenomenon stipulate weak positions of Russia in western ratings of effective use of soft power, which is confirmed by the relevant ratings and indexes.

One of the first indicators of soft power is the Institute for Government-Monocle Soft Power Index, which is being compiled since 2010. Its methodology is based on objective data - statistics and subjective data - interviews. The index is based on three soft power pillars which were broadened to include 5 criteria against which the countries were compared: government, culture, diplomacy, education, business/innovations. This annual index illustrates well the trends in development of Russia's soft power: 2010 - 26 place [12], 201 - 28 place [13], 2012 - 28 place [14], 2014-2015 - 29 place [15]. In different years the top places were taken by USA, UK, France and Germany. Detailed data on indexes for 2013 [16] and 2015-2016 [17] is not available in open access.

One of the most complex indexes of the effectiveness of soft power of states in the world today is the Index «softpower 30», developed by Portland Communications. This indexes evaluates each country by using separate indicators and is the most "precise and current picture of the global distribution of soft power" [18]. Based on the main resources of soft power - culture, political values and foreign policy - authors have developed methodology that consists of $70 \%$ of objective data (statistics) and 30\% - subjective (interviews). Altogether, 65 indicators were used. Based on objective data, six subcategories of indexes were identified, according to which countries were assessed: quality of governance, culture, international presence, education, use of digital technology, entrepreneurship. Based on the general rating according to the main criteria, Russia was not included in Top-30. The list was topped by UK, Germany, US, France and Canada.

By comparing Monocle and Portland Communications indexes and taking into account Russia's positions, we can say that the scale of Russia's use of soft power is not global. Also, Russia's soft power is characterized by particular traditionality, which is confirmed by rusians lover position in rating, where the criteria of use of digital technology was considered.

Another interesting rating, taking into account its grater comprehensiveness is the Elcano presence report 2015 [19], developed by the Elcano Royal Institute (Spain), where the General Global Presence index includes countries' economic, military and soft presence in the world. Elcano rating is build upon divers statistical data. The category of soft presence has the largest 
number of criteria: migration, tourism, sport, culture, information, technology, science, education and cooperation for development.

In the rating of global presence Russia is on the six position, while the absolute leader is the USA. In rating's subcategories Russia has the following positions: economic presence -4 , military presence -2 , soft presence -7 , with reflects that Russia's hard power instruments prevail over the instruments of the soft power.

Thus, not withstanding, the traditionality of Russia's soft power, as well as attractiveness due to its nondemocratic nation and peculiar secondary nature of Russia's soft power, soft power instruments are still being used by Russia in its foreign policy, and therefore, can ve the subject of research.

In his preface to Research Portland Communications J. Nye said that successful use of soft power relies on trust: "when government's actions are perceived to be manipulative and information is viewed as propaganda, the trust is ruined. The best propaganda - is not propaganda" [18]. Secondary use of soft power by Russia, particularly in the region of Eastern and Central Europe shoves that propaganda may be a precondition for successful use of soft power instruments.

"Soft power speaks to people and societies, and not to governments and elites", - points out one of the most prominent theorist of international relations in Russia Andriy Tcigankov. He distinguishes three schools in Russian theory and practice which differently view objectives and methods of soft power use in Russians foreign policy: westernizers, stabilizers and imperialists. Objectives of soft power use are respectively western type democracy, stability and security, political and economic domination: methods: silent cooperation, combination of cooperation and coercion and coercion: political pressure, economic sanctions and support of separatists [20]. As of 2013 an his analysis of the current use of soft power by Russia, the author conceders Putin to be a stabilizer, however as of today his assessment can be objectively considered outdated.

As it was noted about, Russia declared itself to be a great power almost immediately after its independence. Gradual recognition of importance of use of soft power instruments for busting Russia's competitiveness has justified the development of world-view concepts. The concept of "Russian world" become one of the mainstream concepts in Russia, witch, according to Putin's 2006 speech, "Can ensued unite everybody, who deeply cares about Russian language and Russian culture wherever they live - in Russia or beyond its borders [21]. One of the first steps towards the implementation of the concept became establishment of the foundation "Russkiy mir" 2007 [22] and Federal Agency for CIS, countrymen living abroad and on international humanitarian cooperation "Rossotrudnichestvo" [23]. Establishment of this structures was preceded by establishment in 2005 of the Office of the President of the Russian Federation on Interregional end cultural relations with foreign countries, witch confirmed that authorities have started to take soft power more seriously.

Although after dissolution of Soviet Union Russia has inherited grate military potential, it has largely lost its cultural and ideological attractiveness [24], witch cost weakening of Russians positions as a guide for other states. According to the polish researcher Cwiek-Karpowicz J. Russia maintains it resources for attractiveness witch are linked for at list 4 elements: waste employment market, language and general cultural similarity, as well as reach energy resources [24]. However outside Russia the prevailing idea is that Russia's attractiveness to a greater extend is build upon artificial needs and past greatness, witch must allowed to achieve new ambitious geopolitical goals in the absence of sufficient reassures. According to authors of the Washington Post Russia's soft power is based on a peculiar bland of the state supported ideol- 
ogy of national exclusiveness, manipulation with symbols and nostalgia about the carefree base of soviet past [9].

Taking into account the particular content of soft power, which makes its universal attractiveness impossible and its oriented on a relatively narrow range of actors, one can say about existence of conditions foe effectiveness of Russians soft power. The author believes that it is worthwhile to speak about a background that has particular structure. Components of this background are rewired for effective use of soft power by Russia (for communication of certain ideas and priorities).

Population. Use of soft power instruments by Russia is especially effective in the areas with Russian-speaking population. This simplifies the process of conveying key messages of the Russia-oriented mindset. Use of Russian-speaking population of other countries and population of Russian origin as an environment where the use of Russia's soft power is possible (when the foreign country and its citizens are the target) actualized in early 2000-ies, particularly after Putin was elected President. According to Artem Kureyev, expert of the Moscow analytical centre "Helsinki+", Kremlin realized that countrymen living abroad are a source of influence and can be instruments of soft power. Russia strives to reclaim its status of a great world power and thus should demonstrate its readiness to take care of the former Soviet citizens, who have cultural or linguistic ties with Russia [25].

Media component. Russian media presence is one of the key components of successful use of soft power. Regular communication channels are established with the societies of respective countries through a media network and social media pages. The central role in the strategy of Russia's influence on neighbors aimed at popularizing of the worldview that is in line with Russia's national interests belongs to state control on popular media and availability of Russian state channels for Russian-speaking viewers abroad [9]. One of the most popular Russian media oriented at the foreign audience is the channel "Russia today" which broadcasts in all most common languages (English, Spanish, Arabic, Russian, German and French). Russian social network Vkontakte remains the most popular social media network in post-Soviet countries with the largest number of users. Regular communication and exchange of ideas and opinions takes place within this social network, as well as others (Facebook, twitter etc.), through a large number of pro-Russian communities, groups and pages.

Cultural and education component. Reactive nature of Russia's policy to the world trends allows to foresee formats of Russian presence abroad. Cultural and education component of the foundation consists of a network of pro-Russian NGOs, foundations, Russian cultural centers, Russian departments in Universities etc. The latter do not necessarily have to be pro-Russian, unlike others, but substantial attention to and engagement in Russia's information space makes them a target for soft power influence and often makes them repeaters of Russia's massages. The most influential organizations and strictures in Russia witch are a part of a cultural and educational component are the abovementioned Foundation "Russkiy mir" and Federal Agency for CIS, countrymen living abroad and on international humanitarian cooperation "Rossotrudnichestvo". This structures support and communicate with proRussian organizations abroad.

N. Penro, Carnegie Council author sais that "For many analysts the term "Russian mir" encompasses expansionist and messianistic foreign policy of Russia, as well as intertwined confluence of the interests of Russian state and Russian orthodox church[26]. Thus, the religious network of Russian orthodox church of Moscow patriarchate can be also considered as a part of cultural and educational component.

Economic component. Economic component includes Russian business abroad or local business linked to Russian capital. Russians presence in energy sector plays a key role. Russians expert Andriy Tcigankov rises this issue in his research titled "If not with tanks then with banks? 
The role of soft power in Putin's foreign policy" [20], where he particularly speaks about controlee over energy sector and about economy support to no recognized separatist state formations in post soviet countries

Political component. Political component as a rule derives from economic or population components. Prorussian political parties and individuals act with an objective to protect interests of population groups, capital or implementation of geopolitical planes of the center (Russia). Russian lobby can exert substantial influence on decisions in energy sector and on political decisions regarding how to view Russians actions on international arena, in a country where this lobby exists.

The degree of availability of the above components defines effectiveness of the use of soft power instruments of Russia. It should be also noted that this components are interconnected and are often contributing to each other's existence. So we can speak of existence of a network or system, the elements of which are interconnected, have common goals and envisage regular opportunity for communication and influence. Taking into account that some elements act at the same time as actors and targets of influence, the interrelated influence makes communication (transfer) of ideas through this system lass resource intensive and allows to use one element of the system for primary transfer of a message or idea (repeaters). Taking into account the common objectives, elements of the system are also characterized by the high level of endorsement end acceptance of each other' actions and ideas. This takes us back to the question of a nature of Russians soft power and allows to say that it is based not on the objective attractiveness or universality, but on a commonality through alternatively and collective distinction which is based on certain common features: Russian language, orthodox religion and anti-western view.

Use of soft power by Russia in Europe is done under difficult conditions, taking into account the anti-Russian (or anti-communist) convictions of the society in some countries, related to a range of historic events. It is particularly relevant for those European countries that used to belong to the Soviet area of influence and have particularly acute lack of acceptance of Russia's goals for reclaiming the position of a world leader, which is linked to the absence of a broad foundation for effective use of soft power instruments.

Russia's achievements in the use of soft power influence in the countries of Visegrad group are related to history and first and foremost are explained by the knowledge of the context, existence of Russian-speaking population (or people who learned Russian), existence of anti-western views, objective wish to stay out of the zone of potential conflicts, etc.

Important objectives of soft power use are firstly, building of a public opinion, policies loyal towards Russia and in the context of the armed conflict in Ukraine and deterioration of relations with western states - strengthening of anti-Ukrainian positions and positions that justify Russia's actions on international arena, as well as strengthening of counter-integrative ideas within the EU.

Today soft power is a factor that allows to create the so called balance of opportunities in a situation of asymmetric weight of the actors. The nature of soft power lies in the voluntariness to follow the example, which derives from objective leadership, progress and universal values. In practice, one factor rarely defines the direction.

The term soft power today stands in one row with term hard power as an foreign policy instrument, which have different nature. Taking into account that completely different actions of military nature of different countries are qualified as hard power, it can be stated that soft power as as a term can define a broad phenomenon and have different manifestations and formats and not always stay within the frame of the original concept (which in author's opinion is neither full nor final). 
The use of soft power by Russia in a situation of lack of resources for restoration of the direct control over the territories that used to belong to its sphere of influence is objective and predictable. If Russia continued to integrate to the western world, and to associate its own interests with the interests of western countries, Russia's soft power would develop in different direction and would have a less conflict potential (in particular along the line Russia - West).

The use of soft power instruments by Russia is a result of reactiveness of its own policy to western trends and instruments of influence. Russia's soft power is largely based on intentions and declarations, and not on social and political practices, which can be attractive to other countries. Effectiveness of Russia's use of soft power instruments in one or the other area depends on the existing or preliminarily prepared background.

The use of term soft power in relation to the policy of Russian Federation is appropriate, however, there is a need to remember that Russia's soft power can exist in most cases only along other instruments and is secondary in its nature. This testifies to the secondary nature of Russia's soft power and secondary use, when its use depends on the background prepared through the use of other instruments, fo instance advocacy or smear campaigns).

One of the conditions if not for existence as such, but at least for effectiveness of soft power of Russia, is the functioning of non-democratic regimes in the world, which view Russia as a guide. Another pre-condition for Russia's soft power in the countries which are considered nondemocratic is the relevant background.

The difference between Russia's soft power from the original concept and its own vision of this phenomenon explains Russia's weak positions in western ratings measuring effectiveness of soft power instruments, which is confirmed by the data in relevant ratings. Russia uses soft power not on a global scale. Also, Russia's soft power can be characterized by a certain degree of traditionality.

Taking into account the particular substance of Russia's soft power which makes impossible its universal attractiveness and makes it oriented at a narrow circle of actors, it can be stated that there are certain conditions in which Russia's soft power can be effective. It would be appropriate to say that there is a background system which has particular structure: population, media component, cultural and education component, economic and political component. Parts of this background are required for effective use of soft power by Russia.

\section{References}

1. Nye J. Bound to lead: The changing nature of American power / J. S. Nye // New York: Basic Books. - 1990. URL: http://www.kropfpolisci.com/exceptionalism.nye.pdf

2. Nye J. Soft Power / J. S. Nye // Foreign Policy. - 1990. \# 80. - P. 153-171. URL: http:// www.istor.org/stable/1148580

3. Nye J. Soft Power: The Means to Success in World Politics / J. S. Nye // New-York: Public Affairs, 2004 - $191 \mathrm{p}$.

4. Torkunov A. V. Vneshniaia polytyka y bezopasnost sovremennoi Rossyy 1991-2002 / Pod. red. A. V. Torkunova, A. D. Bohaturova y dr. // Moskva: MHYMO, 2002. - 538 s. URL: http://window.edu.ru/resource/986/46986/Mes/mion-ino--centerQ9.pdf

5. Nye J. What China and Russia Don't Get About Soft Power / J. S. Nye // Foreign Policy. 2013.

6. Joseph Nye on global power shifts / YouTube video. URL: https://youtu.be/796LfXwzIUk

7. Heopolytyka postsovetskoho prostranstva: ytohy semynara / Tsentr konservatyvnykh yssledovanyi. URL: http://konservatizm.org/konservatizm/geopolitika/22041 1212811 .xhtml

8. Parshyn P. B. Problematyka miahkoi sylu vo vneshnei polytyke Rossyy / P. B. Parshyn // Moskva: $M H Y M O$, - 2013. № 36. URL: http://www.twirpx.com/file/1Q99542/ 
9. Lankina T. What Putin Gets about Soft Power / T. Lankina, K. Niemczyk // The Washington Post. - April 15, 2014. URL: https://www.washingtonpost.com/news/monkev-gagg/ wp/2014/04/15/what-putin-gets-about-soft-power/Kontseptsyia vneshnei polytyky Rossyiskoi Federatsyy 2013 h. / Ofytsyalnyi sait MYD RF. URL: http://archive.mid.ru/ bdomp/nsPsndpcms17e2f289bea62097f9c325787a0034c255/c32577ca0017434944257b 160051bf7f? OpenDocument

10. Voennaia doktryna Rossyiskoi Federatsyy 2014 h. / Ofytsyalnyi sait MYD RF. URL: http:// archive.mid.ru/bdomp/ns-osndQc,nsf/e2f289bea62097f9c325787a0034c255/ 2a959a74 c d7ed01f432569fb 004872a3 IQpenDocument

11. McClory J. The New Persuaders: An international ranking of soft power/J. McClory // Institute for Government. - 2010. URL: http://www.instituteforgovemment.org.uk/sites/default/files/publications/The\%20New\%20PersuadersII O.pdf

12. McClory J. The New Persuaders II: A 2011 Global Ranking of Soft Power / J. McClory // Institute for Government. - 2011. URL: http://www.instituteforgovemment.org.uk/sites/default/files/publications/The\%20New\%20PersuadersII O.pdf

13. McClory J. The New Persuaders III: A 2012 Global Ranking of Soft Power / J. McClory // Institute for Government. - 2011. URL: http://www.instituteforgovemment.org.uk/sites/default/files/publications/The\%20new\%20persuaders\%20III O.pdf

14. Soft Power Survey 2014/15 / Monocle. URL: https://monocle.com/film/affairs/solt-powersurvev-2014-15/

15. Soft Power Survey 2013 / Monocle. URL: https://monocle.com/film/affairs/soft-powersurvev-2013/

16. Soft Power Survey 2015/16 / Monocle. URL: https://monocle.com/film/affairs/soft-powersurvev-2015-16/

17. McClory J. The Soft Power 30: A Global Ranking of Soft Power / J. McClory // Portland Communications. - 2015. URL: http://dutchcreati veindustries.nl/wp-conterit/uploads/2015/ 07/thesoft power30.pdf

18. Olivie I. Elcano Global Presence Report 2015 / I. Olivie // Elcano Royal Institute. - 2015.

19. Tsygankov A. If Not by Tanks, Then by Banks? The Role of Soft Power in Putin's Foreign Policy / A. Tsygankov // Europe-Asia Studies. - 2006. Vol. 58, \# 7. - P. 1079-1099. URL: https://www.Tantiana.ru/eu4u/Summerschool2013/f\%20not $\% 20$ bv $\% 20$ tanls.fr $<£ 0$ then $\% 20$ by $\% 20$ banks $\% 20$ The $\% 20$ role $\% 20$ of $\% 20$ soft $\% 20$ power $\% 20$ in $\% 20$ Putins $\% 20$ foreign\%20policv.pdf

20. Vyktor Shudehov. Neobkhodymo s novoi syloi vziatsia za problemu podderzhky russkoho yazyka / Ynformatsyonnyi portal Fonda «Russkyi myr». URL: http://www.russkiymir.ru/ fund/press/83728/

21. Ynformatsyonnyi portal Fonda «Russkyi myr». URL: http://www.russkiymir.ru/

22. Россотрудничество / Официальный сайт. URL: http://rs.gov.ru/

23. Cwiek-Karpowicz J. Limits to Russian Soft Power in the Post-Soviet Area / J. Cwiek-Karpowicz // DGAPanalyse. - 2012. URL: https://dgap.org/en/article/getFullPDF/21791

24. Kureev A. Russian Diaspora: A tool of soft power? / A. Kureev // Russia Direct. - 2015. URL: http://www.russia-directorg/opinion/russian-diaspora-tool-soft-power

25. Petro N. Pravoslavnaia "miahkaia syla" Rossyy / N. Petro // CarnegieCouncil. - 2015. URL: http://www. CarnegieCouncil.org/publications/articles papers reports/727 